\title{
Specific functional forms of behavior in pine marten Martes martes, based on snow tracking data
}

\section{Elina J. Vladimirova}

\begin{abstract}
The paper describes the main functional forms of pine marten' Martes martes behavior which include leaving refuge, foraging, change of feeding area, patrolling their territory, locomotion to resting site, rest, and running for safety. Each type of behavior is manifested through a number of reactions which are organized hierarchically. The hierarchy of reactions in mammals is illustrated for the pine marten. The animal's unit reactions, as well as elementary motor reactions they consist of, are listed. As long as the functional type of behavior is correctly identified for a particular animal that left some visible signs of activity in its habitat, its unitary reactions can be discerned in the process of snow-tracking. Human impact changes the structure of behavior in pine martens. The quantity of reactions related to foraging tends to reduce.
\end{abstract}

KEY WORDS: pine marten, tracking technique, functional form of behavior, elementary motor reaction.

Elina J.Vladimirova [elyna-well@nm.ru], Samara State Aerospace University named after Academician S.P. Korolyov, Moskovskoye Schosse, 34, Samara, 443086, Russia.

\section{Функциональные формы поведения лесной куницы Martes martes (по материалам зимних троплений)}

\section{Э.Д. Владимирова}

\begin{abstract}
PЕЗЮМЕ. Дана характеристика основных функциональных типов поведения лесной куницы Martes martes, к которым относили: выход с лежки, кормовой поиск, переход на другой кормовой участок, обход участка, ход на отдых, отдых в лежке, уход от опасности. Поведение определенного функционального типа подразделяется на составляющие. Предложена иерархическая структура поведения млекопитающих на примере лесной куницы. Приведен перечень унитарных реакций лесной куницы, а также элементарных двигательных реакций, входящих в их состав. Если правильно определить функциональный тип поведения особи, которая оставила в биотопах следы жизнедеятельности, унитарные реакции можно распознать в составе следовой дорожки. В антропогенных условиях структура поведения лесной куницы изменяется. Снижается число пищевых и поисково-пищевых реакций.
\end{abstract}

КЛЮЧЕВЫЕ СЛОВА: лесная куница, метод троплений, функциональный тип поведения, элементарная двигательная реакция.

\section{Introduction}

Mammal behavior patterns cannot be used as natural indicators of the animal biotope condition (Sokolov, 2003) without having a formalized description of persistent behavior types. The objective of this paper is to describe the region-specific invariant of behavior pattern in pine martens (Martes martes Linnaeus, 1758).

Ethologists, zoologists, zoopsychologists and computer scientists offered different models of structuring behavior in mammals. For instance, W.R. Ashby (1960) suggested identifying "lines of behavior" based on the actual purpose of behavior. In this work I use a structural model of behavior which is similar to the one proposed by L.M. Baskin (1976: 7-10). Using his predecessors' findings, L.M. Baskin suggested viewing behavior as a combination of large components which he called "activity types". The latter are subdivided in "behavior samples" which consist of "unitary reactions". A unitary reaction suggests being able "to perform a single adaptive act". L.M. Baskin pointed to the difficulty of identifying criteria that would allow taking a unified approach to behavior analysis. He writes off as hopeless any attempts to single out the smallest natural unit of behavior. Indeed, both innate and trained reflexes involve extra movements (Anokhin, 1968). It is also known that muscle contraction patterns tend to be unstable (Hind, 1970). K. Lorenz (1955) hypothesized that species-specific innate motor patterns exist after he analyzed the behavior in closely related bird species, but so far no genetic evidence of such patterns existing in mammals has been found. In describing his experience in tracking the Siberian tiger (Panthera tigris altaica Temminck, 1844), the yellow-throated 
Table 1. Characteristics of field data on pine marten tracks in the Samara Province (1993-2012).

\begin{tabular}{|l|c|c|c|c|c|}
\hline \multirow{2}{*}{ Area } & \multicolumn{2}{|c|}{ Number of animals tracked } & $\begin{array}{c}\text { Total } \\
\text { length of } \\
\text { trails, km }\end{array}$ & $\begin{array}{c}\text { Total length of trails studied in } \\
\text { details, km (with counting } \\
\text { elementary motor reactions) }\end{array}$ \\
\cline { 2 - 6 } & Males & Females & $\begin{array}{c}\text { Sex not } \\
\text { identified }\end{array}$ & 87 & 8 \\
\hline $\begin{array}{l}\text { Oak forest near the city } \\
\text { boundary }\end{array}$ & 8 & 7 & 4 & 135 & 43 \\
\hline $\begin{array}{l}\text { Streamside forest along the } \\
\text { river opposite of the city of } \\
\text { Samara }\end{array}$ & 19 & 30 & 5 & 43 & 7 \\
\hline $\begin{array}{l}\text { Mixed forest (pines and } \\
\text { deciduous trees) in a rural area }\end{array}$ & 6 & 5 & 3 & 235 & 58 \\
\hline Total & 33 & 42 & 12 & & 7 \\
\hline
\end{tabular}

marten (Martes flavigula Boddaert, 1785), the lynx (Lynx lynx Linnaeus, 1758) and the snow leopard (Uncia uncia Schreber, 1775), E.N. Matyushkin (2005) operates with the following terms: species-specific footprint trail elements, points (similar to those of hunting dogs), trail signs of gait changing, behavioral stereotypes, and specific positions. In my opinion, the use of these terms implies the presence of elementary behavior patterns.

A modern approach to system structure analysis (Volkova \& Denisov, 2001) provides a solution to the problem of finding the minimal unit of behavior. This approach consists in "considering the researcher to be an additional element of the system when systems are being built and classified". J.P. Mozgovoi (1980, 2005) suggested using as minimal units of behavior "elementary motor reactions" identified by a field researcher on the basis of winter tracking data. A minimal adaptive function performed by a particular animal may correspond to one or more successive reactions of this kind.

As far as the pine marten is concerned, some scientists believe that this species activity consists of foraging interspersed with moves between mouse-like rodents' habitats (Danilov \& Tumanov, 1976; Sokolov \& Rozhnov, 1979; Grakov, 1981). Species-specific behavioral stereotypes typical for any particular season of the year tend to change in 24-hour cycles (Sokolov \& Kuznetsov, 1978). One animal's activity over a 24hour period, taken as a unit of behavior, is represented by several functional types of behavior which are the focus of this paper. Ultimately, functional forms of behavior can be viewed as successions of elementary motor reactions discernible in winter tracking.

Animal behavior oriented towards satisfying a particular need, which is called motivation (Osgood et al., 1957), forms relatively stable functional types of behavior. In special literature they are also referred to as biological forms of behavior (Krushinskii, 1960), activity forms (Slonim, 1976), types of activity (Sokolov \& Kuznetsov, 1978) and functional forms of behavior (Korytin, 1979; Gaidar' et al., 1983).

The factors influencing animal behavior fall under the following two categories: (1) habitat features and (2) attributes of the inner state of the animal whose behavior is being analyzed (Ashby, 1960). To provide a more detailed description of the second category, it is worth listing the factors belonging in it. They include innate resolution of the animal's receptors, its individual behavioral features (learned reflexes and skills, the nervous system type), its sex and age, as well as motivation and current behavioral context (Severtsov, 1922; Lorenz, 1955; Formozov, 1959; Krushinskii, 1960; Anokhin, 1968; Naumov, 1970, 1977; Baskin, 1976; Sokolov \& Rozhnov, 1979; Korytin, 1986). The behavior of a particular animal can also be influenced by the entire complex of biosocial relations formed within the population and biocoenosis (Shilov, 1977; Panov, 1983; Bol'shakov \& Kubantsev, 1984). For the purpose of this work, let us consider the current need of the animal to be the main factor in its behavior. The intensity of the need determines the animal's motivation (Osgood et al., 1957; Anokhin, 1968; Hind, 1970; Vladimirova \& Mozgovoi, 2006) and, ultimately, forms a particular functional type of behavior.

\section{Materials and methods}

Snow tracking techniques have been the focus of zoologists' interest for a long time (Formozov, 1959; Korytin, 1972, 1986; Mozgovoi, 1976, 2005; Jędrzejewski \& Sidorovich, 2011). The structure of pine marten behaviour was studied in 1993-2012 in three areas within Samara Province by the means of snow tracking techniques. Two of these areas separated by the Volga River are located just outside the city of Samara: one is an oak forest growing on the left bank of the river north of the city; the other is a streamside forest growing on islands close to the right bank of the river. The third area located in the north of Samara Province (west of Kalinovka Village in Krasnoyarsk District) is covered with a ripening forest consisting of pines and deciduous trees. All three areas chosen for the study present a natural habitat for pine martens. In the first two areas the level of anthropogenic transformation of biotypes varies from moderate to high, whereas in the third area it is predominantly moderate and low in some places.

The data collected and processed over the entire period of research includes information obtained from following tracks left in snow over a 24 -hour period by 87 pine martens. The total length of their trails comes near $235 \mathrm{~km}$. Based on some trail features assumptions were made regarding the martens' sex and age (Tab. 1). 


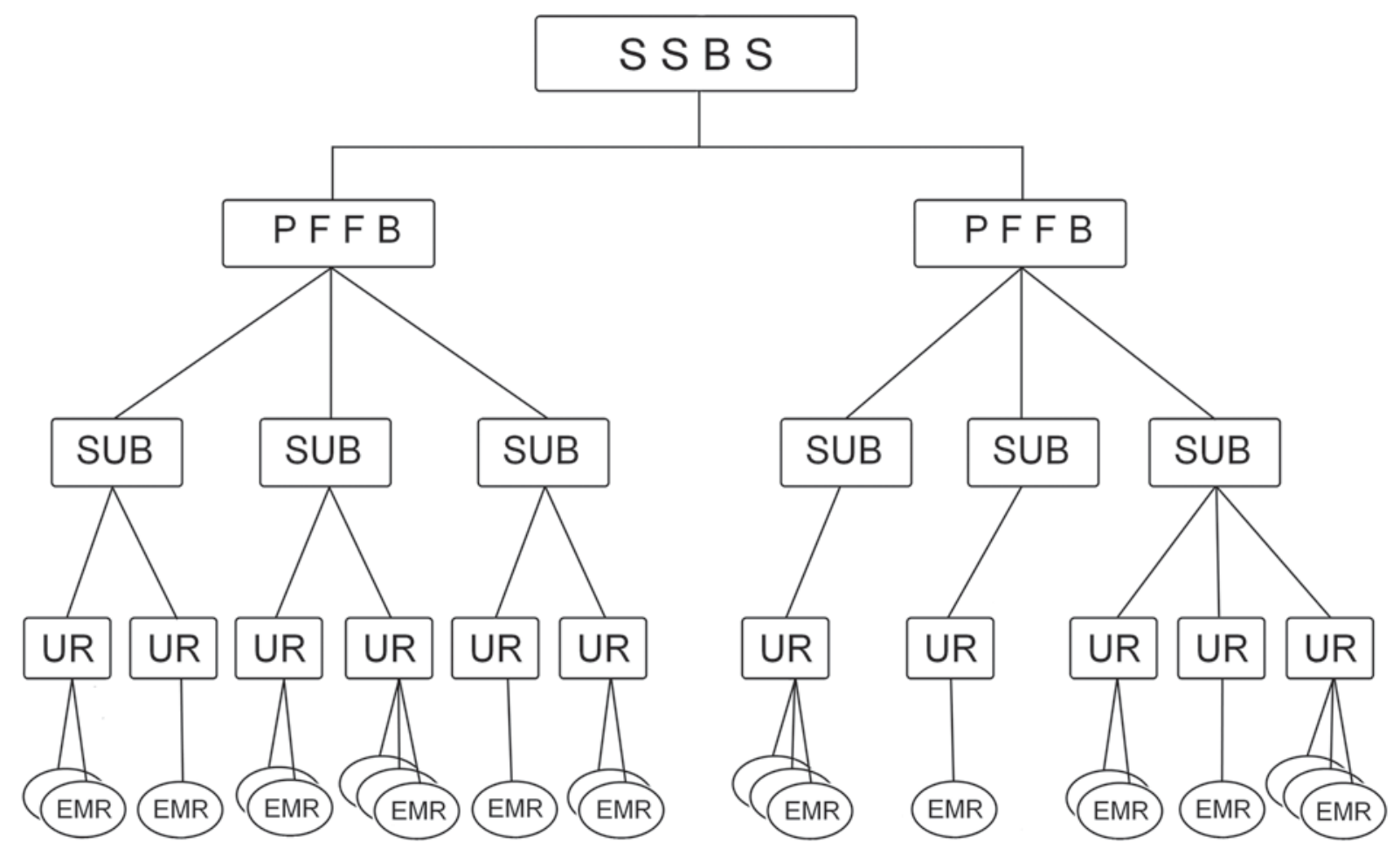

Figure 1. The hierarchical structure of mammals' behavior. SSBS is a species-specific behavioral stereotype typical for the snowy season. PFFB is a particular functional form of behavior. SUB is a situational unit of behavior associated with perception by the animal of an external object. UR is a unitary reaction, which is serving a particular adaptive purpose. EMR is an elementary motor reaction, or invariable movement pattern to which distinctive from other patterns.

The researchers distinguished between young and mature animals, paying attention to the quality and number of elementary motor reactions related to each trail section; they also took notice of external factors/objects which were believed to provoke motor reactions (Mozgovoi \& Rosenberg, 1992; Vladimirova \& Mozgovoi, 2003; Vladimirova, 2009a).

The field data was collected using the detailed tracking technique which allows obtaining comparable quantitative characteristics. This technique is described in the following paragraphs.

When he or she examines a trail of footprints in snow, the zoologist identifies the species of the animal, as well as its movement direction and predominant motivation which is usually alimentary or territorial. The researcher may also take into consideration other information such as biotope features, sex and age of the animal, its functional state, the presence and density of footprints left by conspecific and heterospecific species.

For each particular motor reaction the object that presumably caused this reaction is identified by the snow track pattern, the state of the environment, and the adaptive purpose of the animal's activity. Every encounter with a significant object or phenomenon causes the animal to generate a behavioral response to it (Watson, 1930), or, using J.P. Mozgovoi's terminology, causes the animal to respond with elementary motor reactions (EMR) which can be matched with clearly discernible sections of the continual trail of footprints (Mozgovoi, 1980, 2005).

Dividing the trail into sections corresponding to particular EMRs constitutes the first "step" in doing the research. After that an assumption is made about the external object whose perception by the animal has triggered at least one EMR (sometimes, several EMRs). Making such an assumption constitutes the second "step" in doing the research (Vladimirova, 2009a). EMRs identified through the study of snow tracks (a trail of footprints) combine to make unitary reactions (UR). A UR consists of one EMR or several successive EMRs serving a particular adaptive purpose. Unitary reactions (UR), in their turn, make up situational units of behavior (SUB) which are associated with perception of particular objects in the environment. In some cases the researcher has to admit that it is impossible to identify the external object that has generated a particular SUB. However, such cases are exceptionally rare, which only proves the reliability of the method used. Once the object that generated a response in the animal has been identified, the next step is to determine the functional value of the object. This step consists in analyzing the animal's motivation, in other words, in finding the answer to the question: "What particular functional form of behavior (PFFB) are we dealing with?" In the case of a pine marten it can be foraging, patrolling its territory, locomotion to a different feeding area, loco- 
motion to and from bed, and running for safety (Fig. 1, Tab. 1).

By taking into account the functional type of animal behavior a researcher can "avoid the situation where sets overlap", the expression used by E.N. Panov (2005: 114). In a similar way, knowing the context of a message expressed in a natural human language helps the listener to grasp the meaning of a polysemous word. While examining visible signs of adaptive behavior of an animal a researcher makes hypotheses about two factors: (1) the functional form of the animal's behavior, and (2) the external factor that generated a particular situational unit of behavior (SUB) which, in its turn, consists of smaller units (UR and EMR). The hypotheses made about behavioral units are either proved or rejected based on the observation made by the researcher as he/ she follows the trail of footprints left by the animal in snow. Long sections of the trail representing particular functional forms of animal behavior are considered to prove that the assumptions are correct. This algorithm of splitting the trail of animal footprints into meaningful "quanta" (sections representing various movements) is partially based on works by J.P. Mozgovoi $(1980,2005)$.

The functional quality of the objects is detected alongside with their calculation. Thus, for example, an object may be nutritional, position-finding, promoting secretive or more comfortable motion, etc. Thereby, the functional character of the response behavioral reaction is specified.

Thus, one performs the analytical activity on correlating the token objects perceived by the individual and the "responding" motor reactions. The analysis starts with the separation of the elementary motor response from a continuous chain of tracks, because the "sketches" of the basic movement patterns of a given specimen are already available from the previous experience.

An elementary motor reaction (EMR) is a short behavioral act recognisable by looking at the animal's tracks. It shows as one-type movement with distinctive features by which one can easily see how it differs from the previous and the next elementary motor reaction. Elementary reactions are the same for all animals of any particular species; any such reaction matches a particular track pattern and is an invariant ingredient of a particular functional behavior.

The number of elementary motor responses displayed by an individual to one external object or event, as well as other peculiarities of the accommodation activity, may be analyzed. From the zoopsychological point of view, this index displays the extent of detailed elaboration of the properties of a given environmental object by the animal. From the ecological point of view, the number of elementary responses displayed to one object, points at the conformity of the biological motivation of an individual to the environmental conditions (in particular, the potential of a given object to satisfy any urgent needs of the animal).

The species-specific behavioral stereotype (E) typical for the snowy season has been studied. Within this stereotype the following four sets have been identified: (A) the set of elementary motor reactions, or invariable movement pattern distinctive from other patterns; (B) the set of unitary reactions (UR), which is an EMR or a combination of several EMRs serving a particular adaptive purpose; (C) the set of situational units of behavior (CUB), which is associated with perception by the animal of an external object (it consists of one or more UR); (D) the set of particular functional forms of behavior (PFFB), i.e. a combination of SUBs united by a common long-lasting motivation such as alimentary or territorial motivation, the need to rest, etc.; and (E) the species-specific behavioral stereotype (SSBS) typical for the snowy season (Fig. 1). This allows us to talk about a hierarchical structure of animal behavior (Andreev, 1980; Volkova \& Denisov, 2001).

Identifying an EMR within a UR may present some difficulty, as, in reality, tracks left by the animal in snow may be blurred or vary in shape (the degree of their discernibility depends on the time elapsed between the moment they were left and the moment of their observation, as well as the snow cover depth and density). The researcher memorizes invariants of EMR and UR. Once he/she has identified the functional form of the animal's behavior and made an assumption about the external object that generated a motor response in the animal, the researcher hypothesizes about what happened on the track. The hypothesis is to be confirmed by the events that follow. Reconstructing EMR and UR from animal tracks is somewhat similar to writing a dictation in a foreign language. Even if you are familiar with the method of learning another language, you cannot possibly learn to write a dictation in a language which you do not know before you learn to distinguish meaningful units (words) in a continuous flow of speech by comparing them with samples stored in your memory. In addition to that, you have to understand the general meaning of the sentences dictated. However, we know from our experience that we can overcome this problem, in spite of significant variation in phonemes, accents and regional dialects. This example of a challenge presented by learning a language carries some similarity with the case under consideration, in which EMRs, URs and SUBs are similar to phonemes, words and sentences, respectively, whereas understanding the particular functional form of behavior is similar to understanding the gist.

To illustrate the tracking data collection technique applied, let us look at the picture of a pine marten's trail (Fig. 2). Based on a tape record made in the process of snow-tracking, the researcher wrote in his field log: "The animal loped in an angled two-print pattern". This counts as one elementary motor reaction (EMR). The animal turned left towards the haystack (one EMR), changed its gait (one EMR), then slowed down to walking near the haystack (one EMR) - totally 3 EMRs. The length of the marten's trail section related to the haystack measures $13 \mathrm{~m}$. That object (for example, the haystack) around of which reactions are associated, is 


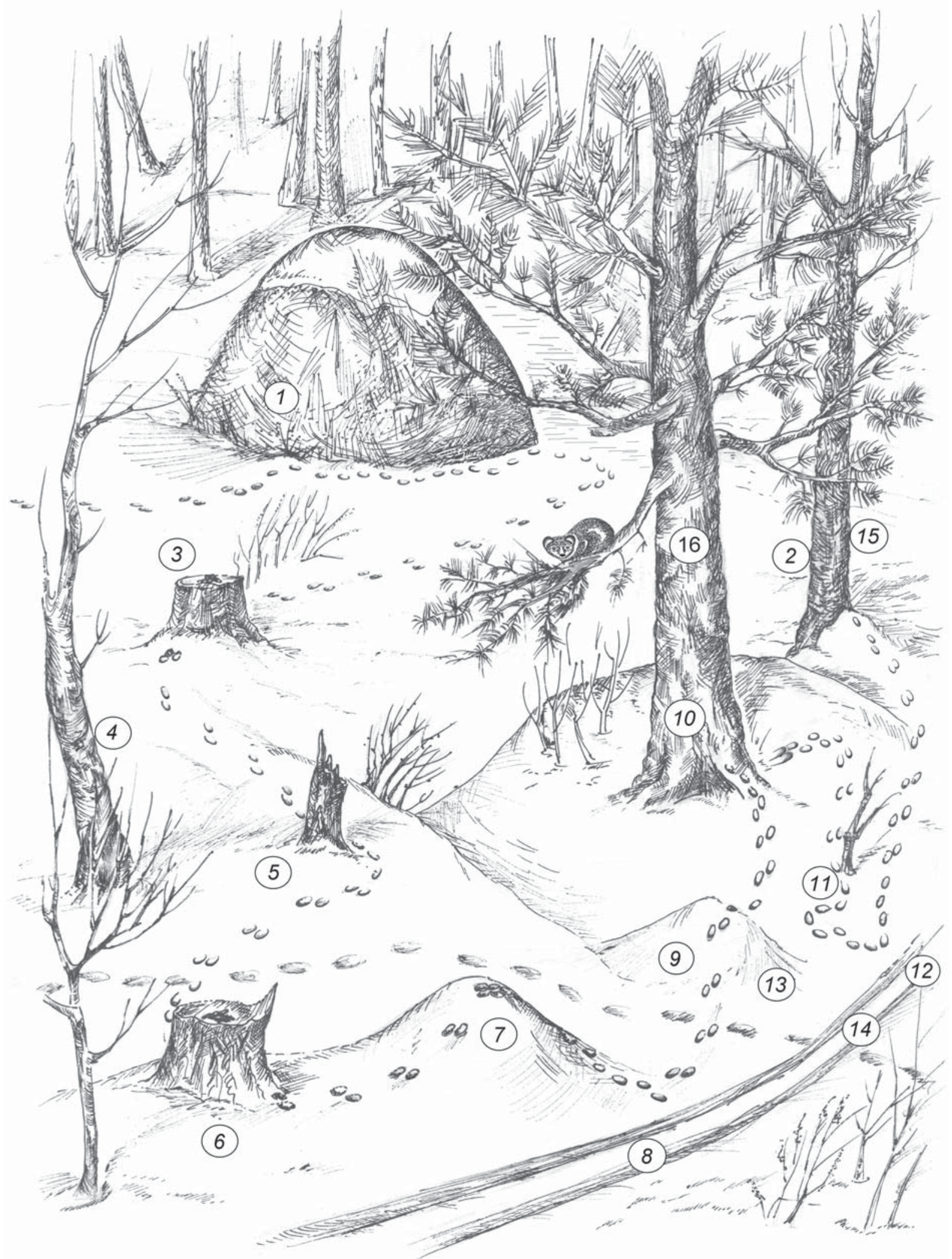

Figure 2. A pine marten trail in streamside forest along the Volga River opposite of the city of Samara. The trail starts in the top left quarter of the picture. It is the beginning of foraging. The total number of situational units of behavior (SUB) is 16 . The number of elementary motor reactions registered is 62 (Tab. 2). The drawing was made by T.V. Shuyskaya, Yu.V. Sachkova and I.V. Vladimirov. 
Table 2. Reactions and external objects of pine marten tracking (Fig. 2).

\begin{tabular}{|c|c|c|c|c|}
\hline No. & $\begin{array}{l}\text { Type of the } \\
\text { external object } \\
\text { which associated } \\
\text { with reactions } \\
\end{array}$ & $\begin{array}{l}\text { Types and quantity of } \\
\text { unitary reactions } \\
\text { performed during the } \\
\text { object perception }\end{array}$ & Types and quantity of elementary motor reactions & $\begin{array}{l}\text { Dista- } \\
\text { nce } \\
(\mathrm{m})\end{array}$ \\
\hline 1 & Haystack & Locomotion (1) & $\begin{array}{l}\text { The marten moved on a ground in two-print pattern } \\
\text { (one reaction), turned left (1), changed the gait (1), } \\
\text { slowed down to walking (1) - } 4 \text { EMR }\end{array}$ & 13 \\
\hline 2 & Pine tree & Locomotion (1) & $\begin{array}{l}\text { The marten made a right turn (1), changed its gait } \\
\text { (switched back to loping in an angled two-print } \\
\text { pattern) (1), headed towards the pine tree (but did not } \\
\text { go all the way to it) (1) - } 3 \text { EMR }\end{array}$ & 4 \\
\hline 3 & Stump & $\begin{array}{l}\text { Locomotion (1), } \\
\text { climbing up the stump } \\
\text { (with jumping off that is } \\
\text { the final part of the } \\
\text { same unitary reaction) } \\
\text { (1) }\end{array}$ & $\begin{array}{l}\text { The marten made a turn to the right (1), loped towards } \\
\text { the stump (1), jumped on it (1), changed its gait to } \\
\text { walking (1) and moved in the same direction (1), } \\
\text { turned left (1), shifted from one foot to another (1) } \\
\text { and jumped off a stump (1) - } 8 \text { EMR }\end{array}$ & 12 \\
\hline 4 & Birch tree & Locomotion (1) & $\begin{array}{l}\text { The marten moved towards the birch tree base ( } 1 \\
\text { EMR) }\end{array}$ & 5 \\
\hline 5 & The smaller stump & $\begin{array}{l}\text { Orientation (1), } \\
\text { locomotion (1), } \\
\text { climbing up the stump } \\
(1) \text {, orientation (1) }\end{array}$ & $\begin{array}{l}\text { The marten oriented a smaller stump (1), turned left } \\
\text { (1) and headed toward a smaller stump (1). Near it the } \\
\text { animal changed its gait (1), started walking around the } \\
\text { stump counterclockwise (1), jumped on it (1), } \\
\text { oriented itself (this reaction is not discernable in the } \\
\text { picture) (1), and jumped off the stump (1) - 8 EMR }\end{array}$ & 5 \\
\hline 6 & Pine-tree stump & $\begin{array}{l}\text { Locomotion (1), } \\
\text { climbing up the stump } \\
\text { (1), marking (1) }\end{array}$ & $\begin{array}{l}\text { The marten loped towards the stump in an angled } \\
\text { two-print pattern (1), jumped on the stump right away } \\
\text { (1), turned left (1) and hovered (1), left droppings (2), } \\
\text { and jumped off a stump (1) - } 7 \text { EMR }\end{array}$ & 9 \\
\hline 7 & Anthill & $\begin{array}{l}\text { Climbing the anthill (1), } \\
\text { orientation (1) }\end{array}$ & $\begin{array}{l}\text { The marten loped in a usual angled two-print pattern } \\
\text { to the top of the hill (1), sat down (1), oriented itself } \\
\text { by the ski track (1), and jumped off the anthill (1)-4 } \\
\text { EMR }\end{array}$ & 6 \\
\hline 8 & Ski-track & $\begin{array}{l}\text { Locomotion (1), } \\
\text { escape danger (1) }\end{array}$ & $\begin{array}{l}\text { The marten made the right turn towards the ski-track } \\
\text { (1), changed its gait (1), walked towards the ski-track } \\
\text { (1) and came within } 0.5 \mathrm{~m} \text { from it. Then it made a } \\
\text { sharp left turn and loped away from the ski-track in a } \\
\text { long angled two-print pattern (that makes } 2 \text { reactions: } \\
\text { the change of gait and the movement itself) - } 5 \text { EMR }\end{array}$ & 2 \\
\hline 9 & Anthill & Climbing the anthill (1), & $\begin{array}{l}\text { The marten climbing the anthill (1) and jumping off it } \\
(1)-2 \text { EMR }\end{array}$ & 3 \\
\hline 10 & Tall pine tree & $\begin{array}{l}\text { Locomotion (1), } \\
\text { climbing the tree (1) }\end{array}$ & $\begin{array}{l}\text { The marten changing the gait for galloping (1), } \\
\text { moving on (1), jumping on the tree(1), and jumping } \\
\text { off the tree into snow (1) - } 4 \text { EMR }\end{array}$ & 8 \\
\hline 11 & Bough & $\begin{array}{l}\text { Orientation (1), } \\
\text { locomotion (1), }\end{array}$ & $\begin{array}{l}\text { The marten oriented itself (1), made the right turn (1) } \\
\text { and galloped towards the bough (1) - } 3 \text { EMR }\end{array}$ & 3 \\
\hline 12 & Ski track & Locomotion (1) & $\begin{array}{l}\text { The marten changed its gait (1), walked towards the } \\
\text { ski track (1) and came within } 1 \mathrm{~m} \text { from it - } 2 \text { EMR }\end{array}$ & 2 \\
\hline 13 & Anthill & $\begin{array}{l}\text { Orientation (1), } \\
\text { locomotion (1) }\end{array}$ & $\begin{array}{l}\text { At this point the animal made a sharp right turn (1), } \\
\text { walked } 1 \mathrm{~m}(1) \text { towards the anthill covered with snow } \\
\text { (the one that it visited before) and made the left turn } \\
\text { towards the ski-track (1)-3 EMR }\end{array}$ & 2 \\
\hline 14 & Ski track & $\begin{array}{l}\text { Locomotion (1), } \\
\text { escape danger (1) }\end{array}$ & $\begin{array}{l}\text { The marten walked towards it (1), stopped at a } \\
\text { distance of } 1 \mathrm{~m} \text { from it made a sharp turn - almost } \\
\text { turned around (1) - } 2 \text { EMR }\end{array}$ & 1 \\
\hline 15 & Pine tree & $\begin{array}{l}\text { Locomotion (1), } \\
\text { climbing the tree (1) }\end{array}$ & $\begin{array}{l}\text { The marten walked towards the ski-track (1), changed } \\
\text { its gait (1), started galloping, headed towards the pine } \\
\text { tree (1), and jumped on it (1) - } 4 \text { EMR }\end{array}$ & 8 \\
\hline 16 & Tall pine tree & Moving in crown (1) & $\begin{array}{l}\text { The marten jumped right onto it from the other pine } \\
\text { tree (1) and skulked on a thick bough (1) - } 2 \text { EMR }\end{array}$ & 6 \\
\hline Total & 16 SCUB & 29 unitary reactions & 62 elementary motor reactions & $89 \mathrm{~m}$ \\
\hline
\end{tabular}


Table 3. The main functional forms of behavior in the pine marten, matched to various motor reactions.

\begin{tabular}{|l|l|}
\hline \multicolumn{1}{|c|}{$\begin{array}{c}\text { Functional forms of } \\
\text { behavior }\end{array}$} & \multicolumn{1}{c|}{$\begin{array}{c}\text { Unitary motor reactions which altogether account for over 75\% of all reactions } \\
\text { corresponding to respective functional forms of behavior }\end{array}$} \\
\hline Foraging & $\begin{array}{l}\text { Ground locomotion resulting in a two-print track pattern, walking, climbing a tree base or a } \\
\text { piece of fallen deadwood, foraging and feeding, digging, eating prey rodents, exploratory } \\
\text { reaction, resting on four paws near a tree, protective orientating reaction }\end{array}$ \\
\hline $\begin{array}{l}\text { Moving to a different } \\
\text { feeding area }\end{array}$ & $\begin{array}{l}\text { Locomotion on the ground by galloping or by leaping in a two-print track mode, orientating } \\
\text { reaction }\end{array}$ \\
\hline Patrolling own territory & $\begin{array}{l}\text { Ground locomotion resulting in a two-print track pattern, orientating reaction, following } \\
\text { own tracks, territorial marking, foraging and feeding, exploratory reaction }\end{array}$ \\
\hline Locomotion to resting site & $\begin{array}{l}\text { Ground locomotion resulting in a two-print track pattern, orientating reaction, climbing a } \\
\text { tree base or a piece of fallen deadwood, changing activity zones, following own tracks, } \\
\text { interruption of attempted locomotion, moving under snow cover, entering a hollow in a tree } \\
\text { (a hollow in a log, debris-strewn shrubbery or a burrow) for resting }\end{array}$ \\
\hline Leaving refuge & $\begin{array}{l}\text { Ground locomotion resulting in a two-print track pattern, galloping, moving in tree crowns, } \\
\text { changing activity zones, defecation and urination, climbing a tree base, foraging and } \\
\text { feeding, protective orientating reaction }\end{array}$ \\
\hline Running for safety & $\begin{array}{l}\text { Galloping on the ground, changing activity zone from ground to trees, moving in tree } \\
\text { crowns }\end{array}$ \\
\hline
\end{tabular}

the nucleus of the situationally caused unit of behavior (SCUB), and so on (Tab. 2). The objects associated with particular reactions form the core of a situational unit of behavior.

The pine marten under concern demonstrated motor reactions to its encounters with the following objects: a haystack, a pine tree, a large half-rotten stump of a pine tree, a birch tree, a smaller stump, a fresh pine-tree stump, an anthill covered with snow, a fresh ski-track, another anthill covered with snow, a tall pine tree, a bough sticking out of snow, the same ski track, the second anthill covered with snow, the same ski track, another tall pine tree, the first pine tree.

In the trail of pine marten footprints shown in figure (Fig. 2) we can therefore identify sixteen fragments corresponding to different situational units of behavior. Those units can be grouped into 29 unitary reactions corresponding in the case under consideration to 62 elementary motor reactions (Tab. 2). J.P. Mozgovoi who developed the theory of sign fields would have said that the sign field of a pine marten is characterized by anisotropy of 16 objects and intensity which is equal to 62 reactions on a footprint trail section $89 \mathrm{~m}$ long (Mozgovoi, 1980, 2005; Vladimirova \& Mozgovoi, 2003).

As we can see from the analysis of the pine marten's behavior in the area shown in the picture, the animal made 6 right turns and the same number of left turns. From studying other martens' behavior we know that their movement pattern becomes less asymmetrical as they grow older. With the younger individuals of the pine marten (and the red fox) left turns prevail over the right turns, whereas the older individuals make the right turns a little more frequently than the left turns (Mozgovoi et al., 1998: 83-84; Mozgovoi, 2005: 25). Certain features of the animal's urinary marks suggest that in the case under consideration we were dealing with a female, although, unlike other female martens, this particular marten seemed to prefer moving on the ground to moving in the tree crowns. A fear of ski tracks in anthropogenic environment is characteristic of female species. Depending on their individual behavior, pine martens of both sexes can be divided into 'tree-climbers' and 'ground-movers', although giving preference to trees is more characteristic of females. In winter time, when the ground is covered with snow, both male and female pine martens use the trees for their locomotion more often than they do in the summer (Mozgovoi, 1976). To identify the sex of a pine marten, we should look at the way its urinary marks are oriented in relation to footprints left by its rear extremities (the more urinary marks we analyse, the more accurate the result is). With male pine martens, which are known to urinate in order to leave special marks, the urinary mark is found in front of the prints left by their rear feet, whereas females leave urinary marks either between, or just behind the prints of their rear feet (Vladimirova, 2009b).

STATISTICA 6.0 program was used to compare the features of particular functional forms (Tab. 4). The sample included equal number of males and females.

\section{Results and Discussion}

On the basis of the data collected in the process of winter tracking the author of this paper hypothesized about the structure of the pine marten's behavior (this behavioral structure is also likely to be present in closely related species of mammals). Analysis of the pine marten's behavior over a several days long period of the snowy season identified the following functional forms of behavior: (1) leaving the diurnal resting location and moving to the foraging territory, (2) foraging, (3) patrolling own territory, (4) locomotion to a differ- 
Table 4. Some features of pine marten behavior in Samara Province (1993-2012).

\begin{tabular}{|c|c|c|c|c|}
\hline Parameter of behavior & $n$ & $\begin{array}{l}\text { Mean } \pm \text { std. error } / \\
\text { min-max }\end{array}$ & Std. dev. & Notes \\
\hline $\begin{array}{l}\text { The average length of a foraging } \\
\text { trail measured from the spot } \\
\text { where the marten left its bed }(\mathrm{m})\end{array}$ & 36 & $\begin{array}{l}602.9 \pm 56.50 / \\
121.0-1419.0\end{array}$ & 339.0 & $\begin{array}{l}\text { It depends on the level of human } \\
\text { impact }\end{array}$ \\
\hline \multicolumn{5}{|l|}{$\begin{array}{l}\text { Proportion of foraging activity in } \\
\text { daily time budget, } \% \\
\text { (Vladimirova, 2009b): }\end{array}$} \\
\hline females & 30 & $\begin{array}{l}73.3 \pm 7.9 / \\
25.7-100.0\end{array}$ & 34.1 & \multirow[t]{2}{*}{$\begin{array}{l}\text { Females foraged mainly at margins of } \\
\text { oak forest or pinery. Foraging station } \\
\text { of males were in divers places, } \\
\text { including the central part of woodland, } \\
\text { the saplings overgrown with bush, the } \\
\text { large wood glades. }\end{array}$} \\
\hline males & 30 & $\begin{array}{l}60.2 \pm 9.2 / \\
17.3-100.0\end{array}$ & 24.5 & \\
\hline $\begin{array}{l}\text { Transit to a different foraging area } \\
\text { (m) }\end{array}$ & 36 & $\begin{array}{c}1219.1 \pm 129.2 / \\
241.0-3060.0\end{array}$ & 764.1 & $\begin{array}{l}\text { It depends on sex of animals and the } \\
\text { condition of marten subpopulation in } \\
\text { phases "low" and "high". The marten } \\
\text { never uses human roads to make easier } \\
\text { its movement. }\end{array}$ \\
\hline $\begin{array}{l}\text { The average length of martens' } \\
\text { trails closely following red foxes' } \\
\text { trails (m) }\end{array}$ & 24 & $\begin{array}{l}75.5 \pm 10.0 / \\
20.0-167.0\end{array}$ & 48.1 & $\begin{array}{l}\text { For years of high density of red fox } \\
\text { population. }\end{array}$ \\
\hline $\begin{array}{l}\text { The average distance that a } \\
\text { marten covered while moving in } \\
\text { the tree crowns for every } 3 \\
\text { kilometers of the animal's daily } \\
\text { locomotion }(\mathrm{m})\end{array}$ & 34 & $\begin{array}{l}811.3 \pm 99.6 / \\
94.0-2410.0\end{array}$ & 104.5 & $\begin{array}{l}\text { For females this distance is } 1.5-3 \\
\text { times higher than for males. }\end{array}$ \\
\hline
\end{tabular}

ent feeding area, (5) locomotion to diurnal resting location. Evidences of yet another functional form of behavior, namely, (6) running for safety, are frequently found in the environment transformed by humans. To the above forms we must add one form observed during false estrus periods: (7) males' invasion into areas controlled by females, followed by activities on borders of such areas. A less frequent modification of this form which is only observed in the cases of small subpopulation (i.e. in the absence of tracks left by males) is locomotion of females to areas with signs of male activity (signs indicating that a male was active in the area in previous years), which is followed by their return to their own territories. Another form of behavior occasionally observed is (8) locomotion between territories settled by different subpopulations. Features of other behavioral forms are presented in the table (Tab. 3). The other key factor in determining the reactions manifested by the animal in a particular situation reconstructed from snow tracks is the context of behavior. In this case the term 'context' is used to refer to behavior characteristics of the time period in which the situation occurred.

Each functional form of behavior is connected with a certain adaptive purpose which an animal with a bodily need is trying to achieve. In addition to that, any particular functional form of behavior can be matched to a specific set of objects on which the animal predominantly focuses its attention while demonstrating this form of behavior. Thus, judging from the snow tracks, a foraging pine marten mostly focuses on the following objects in the environment (the data was collected in an oak grove near the city of Samara): (1) a tree, (2) a bush, (3) a bunch of trunks in the undergrowth shrub layer, (4) debris-strewn shrubbery, (5) tracks left by mice and mouse-like rodents, (6) a piece of fallen deadwood, (7) a stump, (8) a blade of grass sticking out of snow, (9) own tracks, (10) alpine hare footprints, (11) a knoll of snow, (12) a rodent's burrow, (13) roots of an uprooted tree, (14) elk tracks, (15) birds' footprints, (16) leaves and twigs dropped by a woodpecker, (17) shrew tracks, (18) ground dug up by a wild boar, (19) fox tracks, (20) squirrel tracks. Objects which draw the attention of a pine marten moving from one feeding area to another include: (1) an isolated tree, (2) a group of trees, (3) shrubbery, (4) an isolated bush, (5) timber edge or a steep, (6) a river bank, (7) a lake shore, (8) a ravine slope, (9) ski tracks, (10) a road, (11) banked ground along a road, (12) snowmobile tracks, (13) a dead black poplar tree, (14) a piece of deadwood, (15) a stump, (16) cattail stalks, (17) stalks of tall grass, (18) a copse of pussy willows, (19) fox tracks, (20) brown hare tracks, (21) marten tracks, (22) a pylon supporting wires carrying electricity, (23) footprints 
left by passerines, (24) human footprints, (25) ermine tracks.

Snow-tracking of pine martens revealed the following unitary reactions in them: locomotion, self-orienting reaction, hunting, climbing up the stump, escape danger, climbing the tree, moving in crown, eating forage found, leaving marks (e.g. urinary marks, fecal marks or body drag marks), self-cleaning, skulking, climbing fallen deadwood, removing tree bark in search of xylophages, following own tracks, following the tracks of conspecifics and heterospecifics, rolling on the back, digging, interruption of attempted locomotion. In the process of snow-tracking pine martens the following elementary motor reactions were identified: moving in a two-print track pattern, walking and, sometimes, moving in a three- or four-print track pattern, changing gait, stereotype reactions such as stalking, jumping and catching, which are related to catching prey such as mice and mouse-like mammals and birds, faeces excretion, urination, approaching an object to examine it, assuming a sitting or lying position, shifting from one foot to another. Elementary motor reactions related to a particular trail were identified by specific trail patterns, taking into account the general behavior context.

Foraging. Foraging consists of a continual sequence of foraging reactions interrupted by short periods of traveling between mouse-like rodent's habitats. Some authors point out that the area where a pine marten hunts consists of spots where it feeds, which can be identified by signs of digging, and spaces without any indications of hunting in between (Sokolov \& Rozhnov, 1979). When martens search their area for food, they mostly move under the lee of bushes and hillsides in a "tacking" fashion. In their search for food pine martens which feed on mouse-like rodents are mostly guided by such things as the sound and smell of rodents coming from under snow and other indicators of mouselike rodents' presence. The highest numbers of elementary motor reactions in martens are caused by their encounters with the bases of trees and bushes, dry grass stalks, weeds sticking out of snow, stumps, logs, hayricks and stacks of straw. Perception of other objects by foraging martens varies and is characterized by a higher number of elementary motor reactions at the beginning and at the end of foraging bouts. For Samara Province, the average length of a foraging pine marten's trail measured from the spot where the animal left its bed varies (Tab. 4). In the "false oestrus" period the average length may be doubled.

With any particular pine marten the change from any functional form of behavior to foraging occurs several times over a 24 -hour period, especially in case of females and steady animals of both sexes. However, the trail sections related to foraging can be rather short $(100$ to $300 \mathrm{~m})$. It was found that the proportion of foraging in the total amount of daily activities is higher for females (Tab. 4) (Vladimirova, 2009b). As martens are predator mammals, in their search for food they mostly rely on olfactory reactions (Korytin, 1979; Sokolov \& Zinkevich, 1986; Sokolov \& Chernova, 2001). This implies that most of the objects that pine martens encounter and choose not to avoid, are perceived by them as potentially carrying some information related to food; however, males and females react differently to this information: females stay in the lee side of new objects when approaching them, whereas males for which new objects not only potentially carry information on food, but also serve as landmarks, do not take advantage of their sense of smell in deciding from which side to approach them.

In females foraging accounts for up to $60 \%$ of activity (in some cases it exceeds 60\%). In males the functional forms of behavior that can be qualified as "territorial" behavior are observed more frequently compared to those behavioral forms which are connected with foraging and feeding.

Locomotion to a different feeding area. One can easily tell the cases where a marten moved to a different feeding area: in all such cases its track crosses vast open spaces between forest areas and there is evidence that the animal used protective features of the terrain.

When they move to a different feeding area, martens choose the shortest way; the turns and twists of their trail, if any, are caused by the need to use protective features of the landscape (Tab. 4). Female martens almost always climb trees when they encounter any evidence of recent visits of human beings or stray dogs. A marten moving to a new feeding area usually ignores other foraging martens' tracks or any objects which normally arouse martens' interest as potential sources of food; however, after several encounters with signs of other martens' foraging behavior foraging reactions may become prevalent in the behavior of a marten moving to another feeding area.

Statistics for the number of elementary motor reactions registered per $400 \mathrm{~m}$ of trail show that this number depends on the functional form of the animal's behavior. For foraging martens this number is much higher than it is for martens moving to a different feeding area. Conclusions drawn on the differences between the numbers obtained for the two functional forms of behavior (foraging and locomotion to a different feeding area) proved to be credible (to compare the samples the Kolmogorov-Smirnov test was used, all tests were significant at $\mathrm{p}<0.05$, in each sample the number of males equaled the number of females).

While looking for food or moving to another feeding area, pine martens react sharply to encounters with any tracks and traces left by their conspecifics and heterospecifics. In case of conspecifics, a marten following another marten's tracks tries to imitate its behavior; such imitation lasts the longest when the martens' behavior is motivated by the same factors. Females usually imitate the behavior of the males whose tracks they follow; males are more independent in their motivation. In Samara Province, the pine marten can be a commensal of the fox: a marten reacts to encounters 
with a fox's tracks by imitating the fox's movements and, sometimes, by trying to escape; in case of several encounters, within a short period of time, with tracks left by a fox, a marten may even chose to leave the ground and move in tree crowns.

One particular form of behavior mentioned in special literature dedicated to pine martens is patrolling by an individual animal the periphery of its territory (Sokolov \& Rozhnov, 1979). Patrolling own territory is structured similarly to foraging, except it is characterized by longer locomotion vectors between objects on which the animal focuses, and a larger number of reactions specific to territorial marking. This form of behavior is usually observed after snowfalls. Patrolling own territory is a relatively rare form of behavior mostly found in males. It implies the animal's locomotion about its feeding area including its peripheral parts. When an animal inspects its territory, it basically moves around its feeding area, predominantly along the boarders of this area. This particular functional form of behavior often includes leaving behind a smell specific for the weasel family representatives; to mark their territory martens use the secretion of special cutaneous glands, as well as faeces and urine.

Locomotion to resting site, rest and leaving refuge. When martens (both males and females) go to their daytime resting sites, they usually move on the ground and chose shelters near groups of trees or near the forest border. In literature we find controversial information regarding behavioral patterns in martens going to resting site. Some authors think that martens going to bed tend to double on their trail, whereas others claim that martens approaching their refuge never do so. It is true that a marten approaching its refuge moves along straight lines, covering the distance of up to $10 \mathrm{~m}$ while moving in any particular direction. In mammals, moving along straight lines suggests that they demonstrate searching rather than goal-seeking behavior (the form of behavior are reconstructed from snow tracking). According to the author's data on marten behavior in the anthropogenic environment, martens often double on their tracks to trick potential chasers before going to resting site. Such behavior is particularly common in females. As a rule, on the way to their resting location both male and female pine martens make a detour so that they could approach it from the opposite side. If snow is deep enough for them to dig a tunnel, they approach their bed by moving under the snow cover surface.

Researchers registered cases where martens used hollowed oak-trees, snow-covered logs, squirrels' drays and debris-strewn shrubbery for resting. In all those cases, martens seemed to have felt unsafe once they left their refuge, as they chose to move in the tree crowns as far as $500 \mathrm{~m}$ to get from their day-time bed to their feeding area. The cases where martens descended from trees (which sometimes they did) are discernable by the landing marks they left in snow when they jumped off trees to the ground. When they moved in the trees, the martens also left traces on the ground - they dropped snow off tree branches, dropped faeces or debris. After 1 to 4 'trial' descents martens would switch to foraging on the ground.

As soon as they leave refuge, pine martens usually climb trees and move in tree crowns for a while (Mozgovoi, 2005). Martens drop scats not far from their refuge. Both males and females repeatedly make attempts to start foraging on the ground, returning to tree crowns in between (females return to trees more often than males).

Running for safety. In case of danger, pine martens usually climb trees. While running for safety in the open, martens usually move for some time in a three- or four-print track pattern. Encounters with tracks left by other conspecifics running for safety cause imitative reactions in martens, especially in females.

Human impact changes the structure of behavior in pine martens. Studies of pine martens' behavior in anthropogenic environment revealed the following trends: the average length of continual trail sections related to foraging tends to reduce; the frequency of climbing trees from the ground level tends to increase, so does the number of incomplete locomotion attempts, the number of territory-marking reactions, the number of cases of following own tracks, and the number of cases where a martens gallops in a three- or four-print track pattern. Compared to their female counterparts, male pine martens show greater number of exploratory reactions to objects created by human beings; they cover longer distances in their locomotion and, judging by an increase in the proportion of females in martens' population, suffer to a greater extent from the negative impact of anthropogenic transformation of the environment.

We assume that the same structural unit of behavior can be invariable (Mozgovoi et al., 1998). Instead of being identified on the basis of its visible qualities stability, a unit of behavior is identified on the basis of its components' structure and its function on a higher level of hierarchy. Priority should be given to such behavior models whose structural components have a multiple attribution: not only are they classified on the basis of their function, but also on the basis of their relation to time and space. We cannot accept the approach that distinguishes behavior forms on the basis of their "importance for the animal survival capacity". Thus, in this paper, we do not consider such things as "olfactory behavior" (Korytin, 1972) and "social activity" (Baskin, 1976) to be separate behavior types.

\section{Conclusion}

In mustelids which are active in winter time a particular functional type of behavior is recognizable through the localizations of their footprint trails in particular biotopes and through the qualitative and quantitative analysis of behavioral reactions. The fact that trails of pine martens are found in suburban woods within the range of the species population indicates that the level of anthropogenic transformation of the environment in 
the area is not very high, and that the population of martens has not come under threat of extinction. The invariant succession of elementary motor reactions identified by studying martens' tracks generates a particular functional form of behavior which highlights the importance of individual behavioral acts for adaptation. Functional forms of behavior differ from each other in the related numbers and quality of elementary motor reactions and landmarks used by martens. It was found that, with pine martens engaged in foraging or territoryinspecting activities, elementary motor reactions typical of locomotion, orientation, and searching for food prevail.

Thus, we believe that further work on the problem of recognizing functional form of behavior on the basis of elementary motor reactions discrete automaton models should be used. Selective attention, that is, the specificity of the reactivity to the stimuli, which is controlled by the motivating condition of an individual, is characteristic of the accommodative-functioning psyche of living creatures. From all the diversity of signals coming at the animal receptors from the environment, animals react, first of all, to those external stimuli which meet their predominant motivation (i.e. prevailing intention). The sequence of signals forming sign fields is predetermined not only by the spatial characteristics of the environment. The effect provoking the individual's reaction can not be deduced to be the result of simple summation of signal influences; it represents the result of signal integration, complicated by the "internal" mood of the animal, its motivation, experience, skills, physiological condition and the context of behavior. The very process of behavioral performance, its success and longitude, in its turn, influences the individual's perception of certain signals and corrects its further behavior.

ACKNOWLEDGMENTS. The author expresses her acknowledgement to late Prof. J.P. Mozgovoi and Assoc. Prof. O.A. Mozgovaya (Biology Department, Samara State University) for their advice on wildlife ecology. The author wishes to thank and acknowledge all reviewers for their comments that helped her substantially refine this paper.

\section{References}

Andreev V.L. 1980. [Classification Constructions in Ecology and Systematics]. Moskva: Nauka. 143 p. [in Russian].

Anokhin P.K. 1968. [Biology and Neurophysiology of the Conditioned Reflex]. Moskva: Nauka. 560 p. [in Russian].

Ashby W.R. 1960. Design for a Brain. The Origin of Adaptive Behavior. London: Chapman \& Hall Ltd. 411 p.

Baskin L.M. 1976. [Behavior of Ungulates]. Moskva: Nauka. 296 p. [in Russian].

Bol'shakov V.N. \& Kubantsev B.S. 1984. [Mammals' Populations Sexual Structure and Its Dynamics]. Moskva:
Nauka. 233 p. [in Russian]

Gaidar' I.S., Osadchii K.P. \& Gaidar' G.S. 1983. [Basic elements of red fox behavior during the snow period] // [Applied Ethology. Materials of the Conference on Animal Behavior]. Moskva: Nauka. P.203-205 [in Russian].

Grakov N.N. 1981. [Pine Marten]. Moskva: Nauka. 112 p. [in Russian].

Danilov P.J. \& Tumanov I.L. 1976. [Mustelids of the NorthWest of the USSR]. Leningrad: Nauka. 256 p. [in Russian].

Formozov A.N. 1959. [Pathfinder's Guide]. Moskva: Izdatel'stvo MOIP. 320 p. [in Russian].

Hind R. 1970. Animal Behavior. A Synthesis of Ethology and Comparative Psychology. New York: McGraw-Hill Book Company. 812 p.

Jędrzejewski W. \& Sidorovich V. 2011. Art of animal tracking. Bialowieza: Mammal Research Institute, Polish Academy of Sciences. 227 p.

Korytin S.A. 1972. [The variability of mammals' olfactory behavior and its value during evolution] // Abstracts of the First Congress on Ecological and Evolutionary Aspects of Animal Behavior. Moskva: Nauka. P. 212-214 [in Russian].

Korytin S.A. 1979. [Wild Animals' Behavior and Sense of Smell]. Moscow: Izdatel'stvo Moskovskogo Gosudarstvennogo Universiteta. 224 p. [In Russian].

Korytin S.A. 1986. [Wild Animals' Habits]. Moskva: Agropromizdat. 319 p. [in Russian].

Krushinskii L.V. 1960. [Formation of Animals' Behavior in Health and Disease]. Moskva: Izdatel'stvo Moskovskogo Gosudarstvennogo Universiteta. 264 p. [in Russian].

Lorenz K. 1955. Morphology and behavior patterns in closely allied species // Schaffner B. (ed.). Transactions of the First Conference on Group Processes (1954). New York: Macy Foundation. P.168-220.

Matyushkin E.N. 2005. [Carnivorous mammals] // Matyushkin E.N. The selected works. Moskva: KMK Scientific Press. P. 259-626 [in Russian].

Mozgovoi J.P. 1976. [Ethological differentiation in the martens' population of the Southern Ural] // [Issues of Forest Biocenology, Ecology and Environment Protection in the Steppes Zone]. Kuibyshev: Izdatel'stvo Kuibyshevskogo Gosudarstvennogo Universiteta. P.7-14 [in Russian].

Mozgovoi J.P. 1980. [Use of the information biological fields concept in the researches of biogeocenoses] // [Issues of Forest Biocenology, Ecology and Environment Protection in the Steppes Zone]. Kuibyshev: Izdatel'stvo Kuibyshevskogo Gosudarstvennogo Universiteta. P.119-125 [in Russian].

Mozgovoi J.P. 2005. [Information Sign Fields of Mammals: Theory and Practice of the Research Techniques]. Extended Abstract of Doctor of Sciences (Biology) Dissertation. Tolyatti: IEBRAS. 50 p. [in Russian].

Mozgovoi J.P. \& Rozenberg G.S. 1992. [The Biological Sign Field of Mammals: Theory and Practice]. Samara: Izdatel'stvo Samarskogo Gosudarstvennogo Universiteta. 119 p. [in Russian].

Mozgovoi J.P., Rozenberg G.S. \& Vladimirova E.J. 1998. [Mammals' Information Fields and Animal Behavior]. 
Samara: Izdatel'stvo Samarskogo Gosudarstvennogo Universiteta. 92 p. [in Russian].

Naumov N.P. 1970. [Problems of the spatial orientation] // [Animals' Spatial Orientation]. Moskva: Izdatel'stvo Moskovskogo Gosudarstvennogo Universiteta. P. 3-12 [in Russian].

Naumov N.P. 1977. [Biological (signal) fields in the life of mammals] // The Latest Achievements of Theriology. Moskva: Nauka. P.336-398 [in Russian].

Osgood C., Suci G. \& Tannenbaum P. 1957. The Measurement of Meaning. Urbana: University of Illinois Press. $356 \mathrm{p}$.

Panov E.N. 1983. [Animal Behavior and Ethological Structure of Population]. Moskva: Nauka. 423 p. [in Russian, with English summary].

Panov E.N. 2005. [Destinies of comparative ethology] // Zoologicheskii Zhurnal. Vol.84. No.1. P.104-123.

Severtsov A.N. 1922. [Evolution and Psyche]. Moskva: Izdatel'stvo Sabashnikovykh. 54 p. [in Russian].

Shilov I.A. 1977. [Ecological and Physiological Foundations of Relations within an Animal Population]. Moskva: Izdatel'stvo Moskovskogo Gosudarstvennogo Universiteta. 264 p. [in Russian].

Slonim A.D. 1976. [Environment and Behavior. Formation of Adaptive Behavior]. Leningrad: Nauka. 211 p. [in Russian].

Sokolov V.E. 2003. [Study of higher vertebrates in biosphere reserves] // Sokolov V.E. Selected Works. V. 2. Behavior. Ecology. Mammals Protection. Moskva: Nauka. P. 305-307 [in Russian].

Sokolov V.E. \& Chernova O.F. 2001. [Skin Glands of Mammals]. Moskva: GEOS. 648 p. [in Russian].
Sokolov V.E. \& Kuznetsov G.V. 1978. [Daily Rhythms Activity of Mammalian. Cytological and Ecological Aspects]. Moskva: Nauka. 264 p. [in Russian, with English summary].

Sokolov V.E. \& Rozhnov V.V. 1979. [Territorial features, aggression and marking behavior in mustelids] // Archives of Zoological Museum of Moscow State University. No.18. P.163-214 [in Russian].

Sokolov V.E. \& Zinkevich E.P. 1986. [Research of mammals' chemical communications: primary tasks] // [Animals' Chemical Communications. Theory and Practice]. Moskva: Nauka. P.212-219 [in Russian].

Vladimirova E. 2009a. Sign activity of mammals as means of ecological adaptation // Sign Systems Studies. Special issue: Zoosemiotics. Tartu. Vol.37. No.3/4. P.614-636.

Vladimirova E. 2009b. [Research of information processes in zoocoenozes by means of snow tracking] // [Theoretical and Applied Ecology]. Kirov. No.4. P.33-38 [in Russian].

Vladimirova E. \& Mozgovoi J. 2003. Sign field theory and tracking techniques used in studies of small carnivorous mammals // Evolution and Cognition, Vienna. Vol.9. No.1. P.73-89.

Vladimirova E. \& Mozgovoi J. 2006. [Problems of mammals' behavior modeling in a sign field] // Vestnik Samarskogo Universiteta, Seriya Biologiya. No.8 (58). P.322-329 [in Russian, with English summary].

Volkova V.N. \& Denisov A.A. 2001. [Fundamentals of Systems Theory and Systems Analysis]. Sankt-Peterburg: Izdatel'stvo Sankt-Peterburgskogo Gosudarstvennogo Tekhnicheskogo Universiteta. 512 p. [in Russian]. Watson J.B. 1930. Behaviorism. New York: Norton. 308 p. 